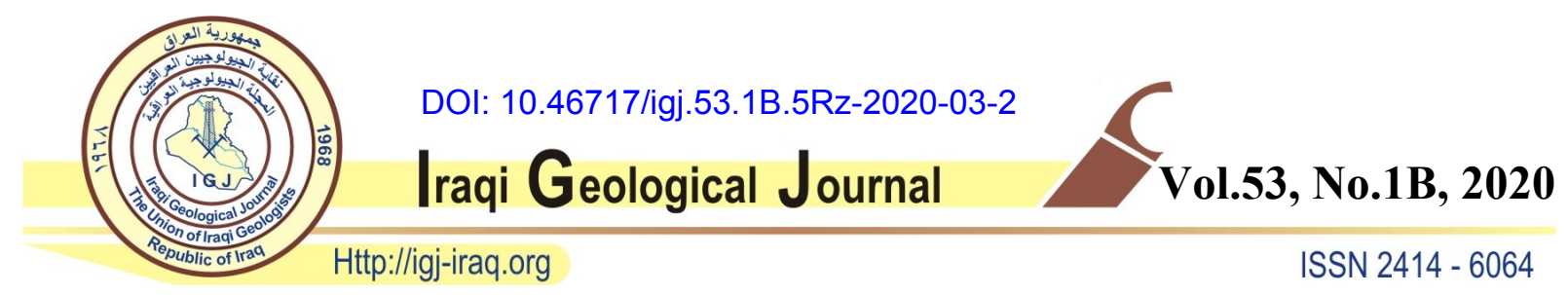

\title{
MICROFACIES DISTRIBUTION OF KHASIB FORMATION IN AMARA OIL FIELD, SOUTHERN IRAQ
}

\author{
${ }^{1}$ Muhand H. Mahammed, ${ }^{2}$ Kamal S. Mohammed and ${ }^{3}$ Karam.R.A. AL-Nqar ${ }^{*}$ \\ $1 \& 2$ Oil exploration company \\ ${ }^{3}$ Ministry of Education, Representative of the Ministry of Education Dohuk \\ *E-mail:Karam.rabah91@gmail.com \\ Received: 9 July 2019; accepted: 2 November 2019
}

\begin{abstract}
The Khasib Formation Late Turonian-Lower Coniacian (Late Cretaceous) is an important reservoir rock in the Amara oil field. Hence, the importance of Petrographic study in this research of Khasib Formation is to know the facies distributions that are summarized in facies models and digenesis affected in the field. Through focusing in AM11, AM9, AM5, AM3, AM12, AM13 wells by using 33 thin sections, RG-log, density and sonic logs that used to the Layering models that have wide engineering applications. The result shows that Khasib Formation consists of limestone and dolomitic limestone. The Khasib Formation has been divided into three microfacies that are deposited in pelagic deep marine environment (deep Cratonic water). The microfacies analysis of the Khasib Formation also is showing that the oil production units in Khasib Formation KA unit (upper part) is made up of Packstone and Grainstone carbonate, but KB unit (lower part) only from Grainstone. The skeletal grains of the Khasib Formation include variety of planktonic foraminifera, Calpionellids and bioclast. The bioclast consists of bivalved shells that belong to Mishrif Formation embedded in micrite and microspare groundmass. The Authogenic minerals consist of pyrite and iron oxide. The rocks of the formation are affected by diagenesis which have a significant impact on the reservoir architecture. The dolomitization is a very important factor to improve petrophysical properties and forming Intercrystalline pores in $\mathrm{KA}$ unit. Besides, dolomitization interprets the relatively height of the $R G$-log in the lower part of $K A$ unit and BAR2. The dissolution has an important role in forming mold and vug pore space in $\mathrm{KB}$ unit and interparticle pores in $K A$ unit. The Cementation is forming impermeable rock (BAR1) in the upper part of the Globigerina Grainstone microfacies (GG3) through forming the granular cement. The chemical compaction has a negative role in petrophysics properties in Khasib units during reaching to the least contact phase and form sutured contacts, irregular stylolite and
\end{abstract}


irregular parallel sutured of micro stylolite set. The microfacies analysis also included oil show description that may be indicated to hydrocarbons concentration. The oil show is high in the upper part of $K B$ unit and in the $K A$ unit hydrocarbons concentrated in the medium and the lower part. The dipocenter is located between AM11 and AM13 wells by the deep basin facies that is noted from facies models. The facies distributions in the sedimentary basin show that the Globigerina Grainstone microfacies is the main component of the Khasib Formation in the lower part. The Globigerina packstone microfacies and Calpionellids packstone microfacies are concentrated in the upper part of the Khasib Formation. Khasib reservoir has been divided into 45 layers depending on log behavior (RG-log, density and sonic) and petrophysical properties that are observed in the Layering model.

Keywords: Amara Oilfield; Khasib Formation; Microfacies

\section{INTRODUCTION}

1. The Khasib Formation in Late Turonian-Coniacianis is one of the most important reservoirs in the Amara oilfield. The type locality of Khasib Formation was in type well locality as defined by (Owen and Nasr, 1958) in Zb-3 consist of dark gray-green shale in the lower part $20 \mathrm{~m}$ and gray marly limestone in the Upper part by thickness $30 \mathrm{~m}$, the total thickness in type locality up to 50m (Dunnington et al., 1959). It seems difficult to apply these divisions in all areas of Khasib Formation distributions because of the difference in the petrographic components. For example, in the case of the absence of gray marly limestone, the upper part has disappeared in the area (Buday, 1980). Hence the importance of the Petrographic study is to define the upper and the lower parts component of the Khasib Formation in the Amara oilfield and the Paleoenvironment. The thickness of the Khasib in the study well is shown in (Table 1). The study aimed to Determining the microfacies type depending on the (Dunham, 1962) classification, distributions of these facies and sedimentary environment according to (Wilson, 1975) standard through the petrographic study, Determining the digenesis processes and their effect on the basin architecture, Design the cross section and Well study correlation of AM11 well and Design the facies and Layering models depended on the petrel software by using GR-log, Density Log (FDS, DRHO, RHOB) and sonic log.

Table 1: The top, bottom and thickness of the Khasib Formation in the studied wells

\begin{tabular}{|c|c|c|c|c|c|c|}
\hline \multirow{2}{*}{ Wells } & \multicolumn{2}{|c|}{ Coordinates (UTM) } & \multirow{2}{*}{$\begin{array}{c}\text { Khasib } \\
\text { Fn. }\end{array}$} & $\begin{array}{c}\text { Top } \\
(\mathbf{m})\end{array}$ & $\begin{array}{c}\text { Bottom } \\
(\mathbf{m})\end{array}$ & $\begin{array}{c}\text { Thickness } \\
(\mathbf{m})\end{array}$ \\
\hline AM.11 & 3518250 & 699500 & Khasib & 2798 & 2874 & 76 \\
\hline AM.5 & 3518450 & 701350 & Khasib & 2808.5 & 2888.5 & 80 \\
\hline AM.9 & 3518952 & 696073 & Khasib & 2790 & 2871 & 81 \\
\hline
\end{tabular}




\section{LOCATION AREA}

The well study area is located southern Iraq in the Amara oil field about $10 \mathrm{Km}$ southern Missan Governorate as it is shown in the Satellite image (Fig. 1) that is obtained from satellites Sentinel-2 according to wells coordinates (UTM) (Report of well.11 MOC, 2011) in (Table.1).

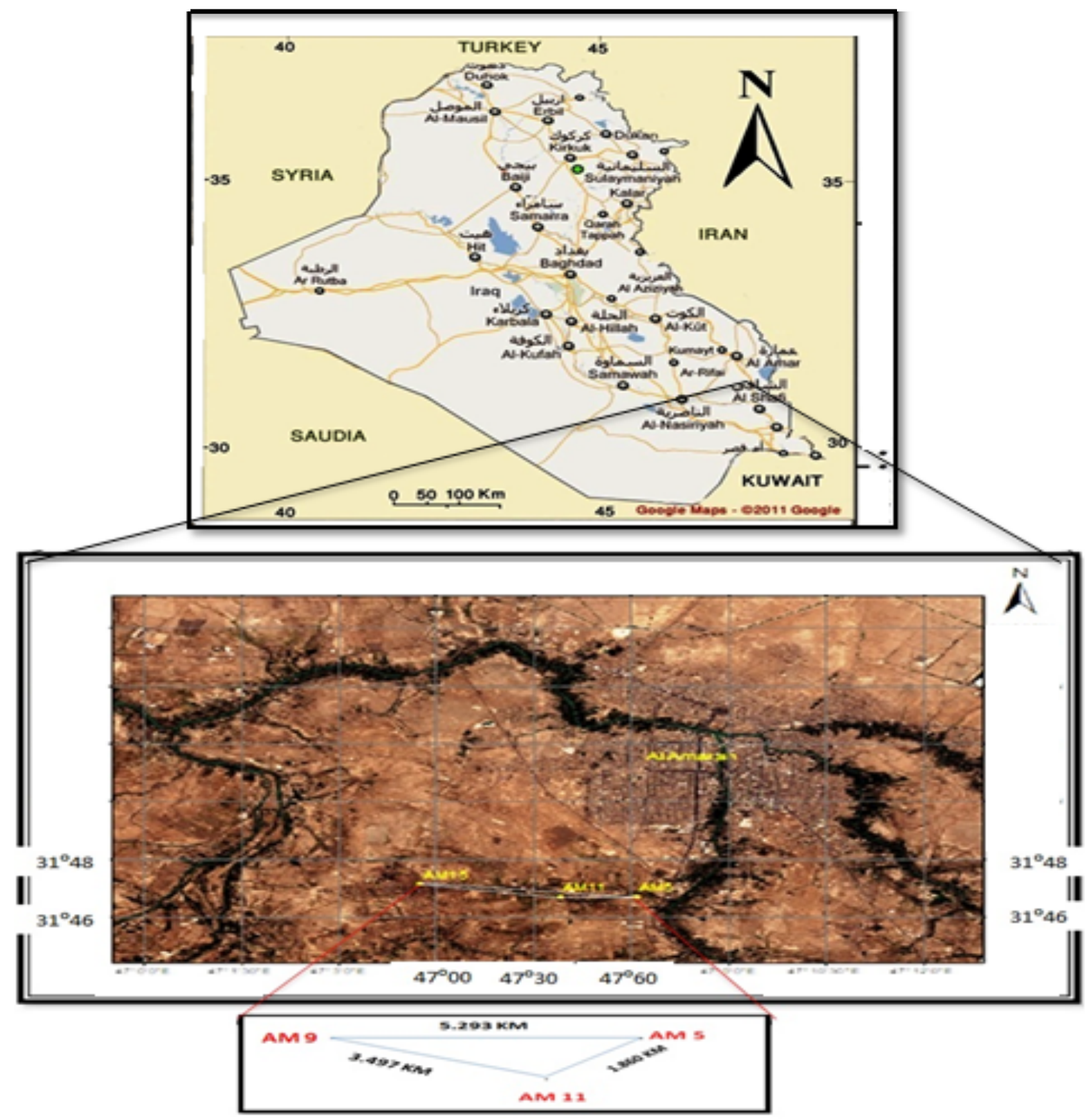

Fig.1: Satellite image of well-studied location from (Sentinel-2 satellites) in Amara oil field

\section{MATERIALS AND METHODS}

This study included six wells which are AM9, AM11, AM5, AM12, AM13, AM3 and these wells are used in Microfacies analysis, design facies and layering models. Microfacies analyses 
use 28 slides that are obtained from Core samples and 5 slides from cutting and these samples were carefully selected from objectives depths to cover the study aims and they were prepared in GEOSURVE laboratory. The total of 33 thin sections are described under a polarizing microscope after staining by red alizarin $\mathrm{S}$ stain. The following properties were observed by petrographic description lithology, mineralogy, textures, diagenesis and oil show. The lithological cross sections of the well study for the Khasib Formation were drawn by using the AutoCAD 2016 Software and Well study correlation is drawn by GR-Log and Microfacies description to specify the vertical extension of the Khasib microfacies by using AutoCAD 2016 Software. Design 2D and 3D facies models after digitizing the well study correlation. Design the Layering model by using GR-log, Density Log (FDS, DRHO, RHOB), sonic log and facies distributions in Petral-2018 Software.

\section{TECTONIC FRAMEWORK}

Missan Governorate is located in the Tigris Subzone in the Mesopotamian Zone. It contains wide synclines and narrow anticlines trending often NW-SE extending by long normal faults (Jassim, 2006). The western boundary synchronizes with a palaeoridge that is effected by sedimentation in the Mesopotamian Zone in the Late Jurassic time. Separating inner shelf facies in the southwest from outer shelf facies to the north east. The Tigris subzone includes two trending groups of lines anticlines (northwest and southeast) which are relatively low spread associated with longitudinal faults and at EW transversal trend. These anticlines are affected by three faults which are Ramadi Musaiyib Fault, Tikrit-Amara Fault and Kut-Dezful Fault. The Tectonic was active from the Late Jurassic onwards. Its border by the Foothill Zone (in NE) and by long gravity gradient and line of residual gravity anomalies between Qal at Salehin southeast and Fallujah northwest (Jassim, 2006).

According to (Darmoian, 1975) the formation in Late Turonian-Coniacian age represents the lower section of Megasequence (AP9). It was deposited in a restricted basin of relatively narrow seaway occupying in Salman, Mesopotamian, Foothill and High folded Zones. RutbaJezira zone was rising in these times, while the Turonian sediments are missed in the northern thrust zone because partial height of Neo-Tethys is in the south. Turonian sediments were fully deposited in Balambo-Tanjero Zone. The lower boundary of Khasib Formation is unconformable with Mishrif Formation (Jassim, 2006) whereas the upper boundary is gradational with Tanuma Formation (Fig. 2), thickness in well study ranging between $76-80$ M (Report of AM11 well MOC, 2011). 


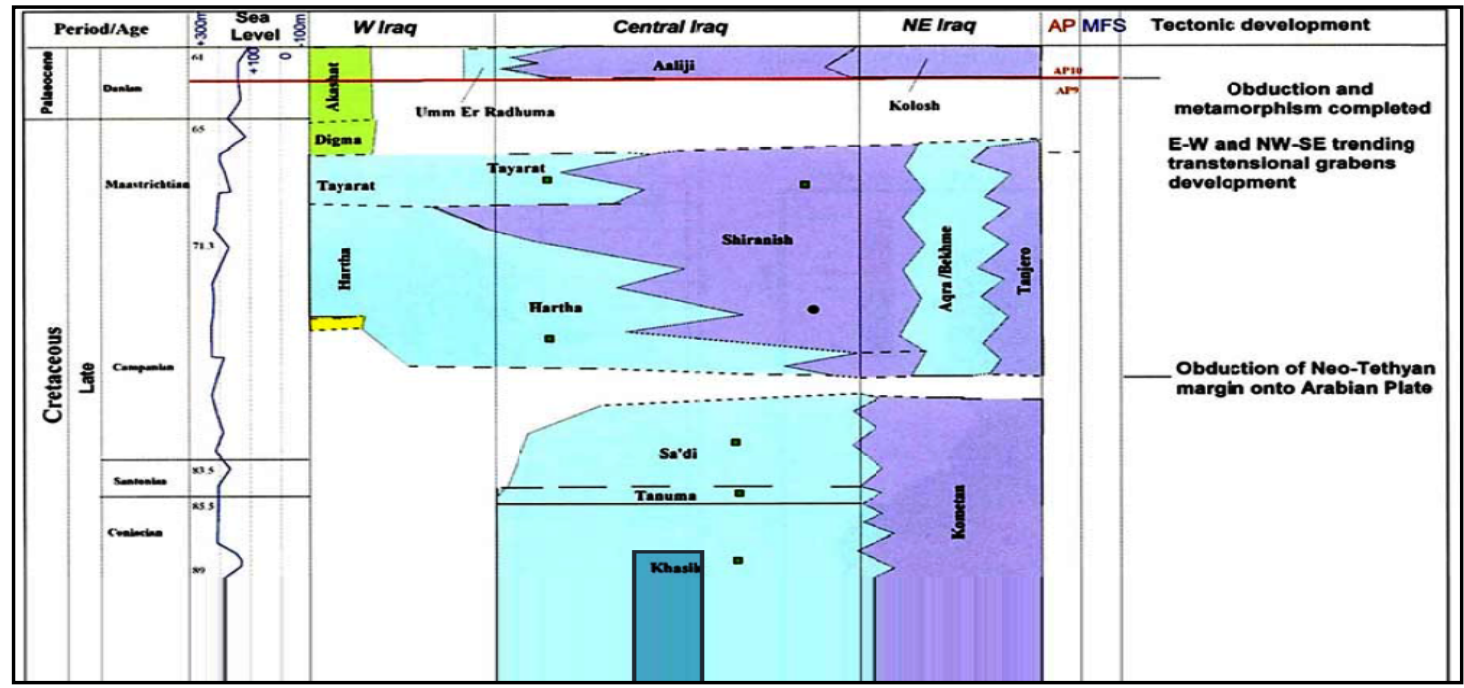

Fig. 2: Stratigraphic correlation in Late Early Turonian-Danian Megasequence (Jassim, 2006)

\section{RESULTS AND DISCUSSION}

This section includes the result of microfacies analyses (a type of skeletal grains, Matrix, pore space and relationship with reservoir unit and sedimentary environment). The digenesis effects on microfacies. All these pieces in the formation are summarized in the cross section of well AM11.

\section{Skeletal Grains}

\section{Planktonic Foraminifera}

The majority occurs in the upper part of the water column within the upper 50 to $100 \mathrm{~m}$ near the surface (photic zone). Below $200 \mathrm{~m}$, they are virtually absent but after the death of these groups are transported by waves to a deep environment to gather and build deep limestone. Planktonic fauna avoids terrigenous input. Therefore, they accumulate in the bathyal depths of open-marine basins.

They represented the rock-building limestone in a Cretaceous deep marine and they have an importance in biostratigraphic markers in the Early Cretaceous (Flugel, 2010). These are the most important species of Planktonic foraminifera in Khasib Formation:

1. Globigerina Spherical test. Wall calcareous is common in Middle and Late Miocene deep shelf and basinal limestone (Flugel, 2010) in Khasib Formation in PL.1A. which are copious present.

2. Globigerinae Note the globular chambers. Genus range: Eocene to Holocene is common in Khasib Formation PL.1B. 
3. Herohelix note biserial growth. The maximum occurred in the Maastrichtian. Late Cretaceous (Van Konijnenburg et al., 1998) PL.1C.

4. Praeglobotruncana. Late Cretaceous test trochospiral, biconvex to spiroconvex, wall calcareous, are common in study well PL.2D.

\section{Calpionellids}

Calpionellids are extinct bell-shaped and very small calcite microfossils. Pelagic limestones of Late Jurassic and Early Cretaceous Tethyan ocean. The planktonic fossils are considered as a group of the subphylum Ciliophora (Flugel, 2010). Calpionellid stratigraphy is generally combined with biozonations based on calcareous nannoplankton (nannoconids, coccolithophorids) and radiolarians (Flugel, 2010). Calpionellids are found in common presence in Khasib Formation PL.2E.

\section{Bioclast}

Organoclastsare organic particles of various origin with or without structure (Tucker, 2001). In Khasib Formation the, univalved shells are thin bivalved shells is the main type of bioclast at a rare presence up to 2-3\% with subangular - subroundedin sphericity PL.3D.

\section{Matrix}

As it is noted in the Khasib Formation, the major constituents that are seen in thin sections of carbonate rocks are 'groundmass'. The spray calcite is latter developed as fine-grained carbonate 'matrix' or as representing pore-filling cement or recrystallized from micrite.

The micrite is commonly regarded as an indicator of low-energy depositional environments in protected shallow areas or Pelagic sea floor (Flugel, 2010) as noted in the Khasib Formation lamination micrite with abundant planktonic foraminifera PL.2B.

\section{Pore Space}

This study uses (Choquette and Pray, 1970) classification that has shown the importance of relating pore space to depositional and digenetic fabrics and of distinguishing between pore space types in reservoir study which are shown in below:

1. Moldic pores are fabric selective secondary pores from the selective dissolution of grains by solvent liquid. Preferentially, Molds form in rocks of mixed mineralogist in burial settings. Generally, pore sizes are 0.1 to $10 \mathrm{~mm}$ which are very commune in $\mathrm{KB}$ unit (lower reservoir unit) in Khasib Formation are the basic pores PL.2F.

2. Interparticle pores: Pores between individual particles generally agree with depositional primary porosity, pore sizes are 0.05 to $1 \mathrm{~mm}$. Interparticle pores are high in modern carbonate deposited (up to about 50\%) and in the study reservoir is not more than $(2-3 \%)$ in Khasib Formation PL.3A. both of KA (upper reservoir unit) and KB unit. 
3. Vug pores: non fabric selective formed by synsedimentary to early digenetic biogenic methane freedom organic matter is common in KB unit Khasib Formation in PL.3C.

4. Caverns: non fabric selective is uncommon presence PL.3A.

5. Fractures: non fabric selective uncommon in KA unit in the Khasib Formation PL.3B.

6. Intercrystalline pores: a medium to coarsely crystalline replacement dolomite are the main pores in KA unit PL.3C.

\section{DIGENETIC AND POROSITY MODIFICATION}

The Khasib Formation is characterized by homogenous components. This led to regularity in the distribution of pore system in the description of the Microfacies. The basic digenetic processes are discussed below:

\section{Dolomitization}

The diagenetic process that converts limestones to dolostones through a microchemical process of calcium carbonate dissolution and dolomite precipitation. In the Khasib Formation, the partly dolomitization doesn't form distinctive rhomb crystals of dolomite PL.1F. The dolomitization is indicated to replace from grain-dominated fabrics and has a positive role in petrophysics which is characterized in AM11, AM9, AM5 wells in (KA) unite. Therefore, dolomitization is a very important factor to improve petrophysical properties because of (1) increasing particle size (2) developing intercrystalline pores and (3) raising resistance to compaction (Lucia et al., 1995).

When the dolomitization forms dolomitic limestone, which is destroying the pore space system and building the (BAR2) between the two reservoir units in Khasib Formation PL.2A. Because of the grain dominated are usually consisting of grains much larger than the dolomite crystal size, that dolomitization does not have an important influence on the pore-size distribution (Lucia, 2007).

The main dolomitic texture in Khasib Formation is Aphanotopic crystals of dolomite in (0.002) $\mathrm{mm}$ size. It is formed by the homogeneous dolomitization of micrite (Randazzo and Zachos, 1984). When crystals size is more than $0.002 \mathrm{~mm}$, it is known as Microcrystalline texture. According to (Randazzo \& Zachos, 1984) it was noted that this type of dolomite is formed by early dolomitization but it is commonly presented in Khasib Formation.

\section{Carbonate Cementation}

Cementation can be formed by sin sedimentation or may occur later during burial. Later cementation may occur by a complex geochemical-hydrological meteoric flow system. 
Therefore, the pore space has been cleared totally from carbonate from some around and reprecipitation in other areas (Budd, 2002).

A characteristic of all cement is that they are growing from pore wall into pore space and therefore reducing pore size. The methodology of reduction in pore size accounts for the observed systematic changes in permeability PL.3B when filling cavern and fracture. In the Khasib Formation and forming impermeable rock (BAR1) in the upper part of the Globigerina Grainstone microfacies (GG3).

Cementation in the Khasib Formation form the granular cement which is calcite cement that is consisting of relatively equals pore-filling small crystals texture PL.3F. Common in interparticle pores in burial environments are formed by recrystallization of pre-existing cement are copies present.

\section{Compaction}

The compaction is resulting from the increased overburden pressure due to the burial. Textural effects include the loss of porosity, reduction of pore-size, grain penetration, grain deformation, grain breaking and fracturing (Budd, 2002). The least contact phase is observed between the grains in Khasib Formation which is described as concavo-convex, tangential, sutured contacts and two sets of cleavage forming in the high physical compaction PL.3G (Tucker, 2005). Khasib Formation in thin section for the same sample display irregular stylolite PL.3E. Also, in other state, thin section shows irregular parallel sutured seams Bedding-parallel (micro stylolite set) PL.1E. The effect of compaction varies depending on the type of the microfacies if grain-supported limestones grainstones, packstones. The Stylolites are very clear as it is Shawn in Khasib Formation (Tucker, 2005).

\section{MICROFACIES DISTRIBUTION IN KHASIB FORMATION}

The lithology of Khasib Formation consists of grain dominated carbonate (planktonic microfacies) which is divided into three Microfacies (Fig. 3)

\section{Globigerina Grainstone microfacies (GG3)}

This microfacies has Globigerina genus high ratio about (90\%) embedded in microspar ground mass with lamination Bituminous limestone. Depth is from 2831 to $2872 \mathrm{~m}$ and thickness is $41 \mathrm{~m}$.

This microfacies mostly is affected by dolomitization ranging between $40-45 \%$ which causes deformations to all skeletal grains. Cementation generated granular cement. The visible pore space intercrystalline and intrapartical ranging between $4-5 \%$. Oil show is ranging about highmedium. 
This microfacies (GG3) is repeated in the other depth which is ranging between 2809 $2817 \mathrm{~m}$ and thickness is $9 \mathrm{~m}$. This microfacies consists of Dolomitic limestone which involves planktonic foraminifera PL.1A, B. Skeletal Grains are the basic components and one of these components is the planktonic foraminifera which is about $60 \%$ and the other components is Calpionellids which is about $30 \%$. The groundmass is modified completely to isopachous and Blocky cement.

Digenesis are summarized by compaction which is shown in sutured contact and in the last five-meter dolomitization which causes deformations to all skeletal grains. Pore space is mostly formed by selective dissolution moldic and vug PL.2F. and is ranging between 6 to $8 \%$. Oil show is sometimes medium and sometimes high. This microfacies is forming KB unit in Khasib reservoir PL.3H.This microfacies has a high ratio of pyrite at a depth $2817 \mathrm{~m}$. Another appearance for this microfacies at depth 2798 Khasib top - to $2807 \mathrm{~m}$ and thickness about $9 \mathrm{~m}$. This microfacies contains skeletal grains more than $90 \%$ from planktonic foraminifera only (Globigerina, Globigerinid, Praeglobotruncana) PL.1C and embedded in microspare groundmass.

Cementation consists of granular cement. The chemical compaction creates sutured PL.1D and stylolite PL.1E.Physical compaction led to forming large crystals of calcite manufacture having two sets of cleavage and this is the phenomena which is the result of of high compaction.

Vug and mold are the main pore spaces type with low-medium oil show. This part is forming BAR1unreservoir unit in Khasib reservoir. According to (Wilson, 1975) this microfacies is similar to the standard Microfacies (SMF3) which is originally precipitated in (FZ1) Gratonic deep water basin.

\section{Globigerina packstone Microfacies (GP1)}

This microfacies consists of bituminous limestone and dolomitic limestone including low percentage of skeletal grain 50-55\% and maintain a good variety Globigerina PL.2D embedded in micrite ground mass and it includes Pyrite.

The depth of this microfacies is about 2826 to $2830 \mathrm{~m}$ and its thickness is about $4 \mathrm{~m}$. The effective digenesis process is represented by dolomitization that destroys facies features. Compaction is existed by sutured and stylolite. The pore space is ranging about $13 \%$ with mold spores, channel pores and intercrystalline. This microfacies includes high oil shows and forming the lower part of KA unit in Khasib reservoir.

According to Wilson (1975), this microfacies is similar to the standard Microfacies SMF4 in originally precipitated in FZ1 Gratonic deep water basin. 


\section{Calpionellids Packstone Microfacies (CP2)}

This microfacies showed an increasing of the Calpionellids fauna about $75 \%$ bioclasts embedded in micrite. In addition to, high percentage of Pyrite PL.2C.

Thickness of this microfacies is about $8 \mathrm{~m}$ and depth is about 2818 to $2826 \mathrm{~m}$. The effect of digenesis is cementation (isopachous and drusy types) and Compaction that is summarized in laminated limestone PL.2B sutured, stylolite contact and twinning calcite. This microfacies is also featured by dolomitization that deforms facies style in some time PL.1F and PL.2A. The Pore space is intercrystalline, mold, intrapartical and vug which is ranging between $8-10 \%$. Oil show is low. This microfacies is forming the middle part of KA unit in Khasib reservoir. According to (Wilson, 1975) this microfacies is similar to the standard Microfacies SMF3CAIP and it is originally precipitated in FZ1 Gratonic deep water basin.

\section{CROSS AND CORRELATION SECTIONS}

After completing the above-mentioned comparison (Microfacies and Reservoir unit to determination the type of facies for these units and with Oil show observer in thin section) the following points are observed:

1. Cementation has a negative role in Khasib Formation by forming BAR1(impermeable rope) which is included in Globigerina Grainstone microfacies (GG3). The cementation proses converted Grainstone facies to Cap rock reservoir.

2. The BAR2 (impermeable rope) in Khasib Formation consists of Dolomitic limestone.

3. The oil production units in Khasib Formation KA unit is made up of Packstone and Grainstone carbonate. The KB unit is only made from Grainstone which is deposited in deep Cratonic water environment.

4. The GR-log reading is relatively high in BAR2 and lower part of KA unit and the initial interpretation through the microfacies analysis due to the dolomitic limestone according to (Hassan, 1973) and partly dolomite in the lower part of KA unit where the KB unit is a clean reservoir.

5. Oil shows which might be indicated to hydrocarbons concentration, is high in the upper part of KB unit and medium in the lower part for the same unit. In the KA unit, the concentration of the hydrocarbons is high in the medium and the lower part. 


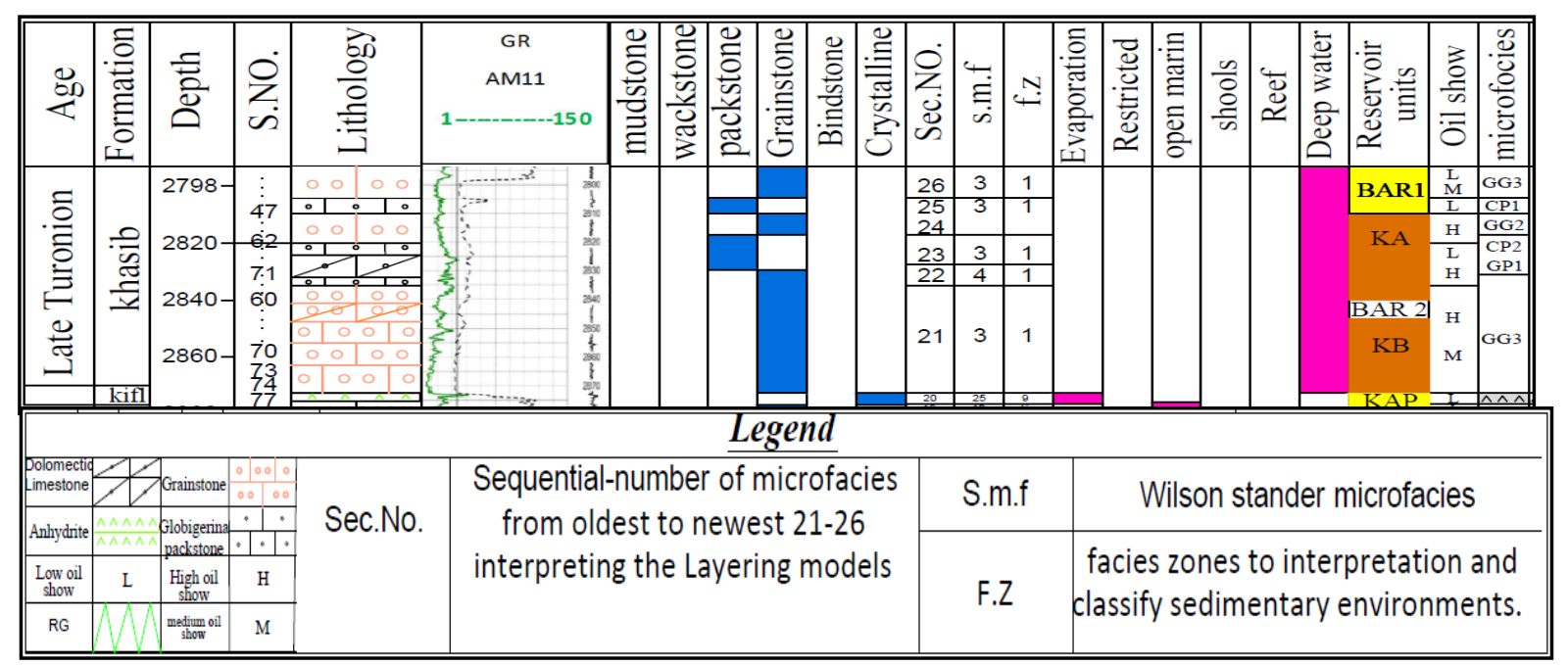

Fig.3: Cross section of well AM11 in the Amara oil field of the Khasib Formation

The cross section of well AM11 has been used to draw correlation diagram between wellstudied AM11, AM9, AM5 and GR-Log to determine the limited of microfacies description in well AM5, AM9 wells (Fig. 4).

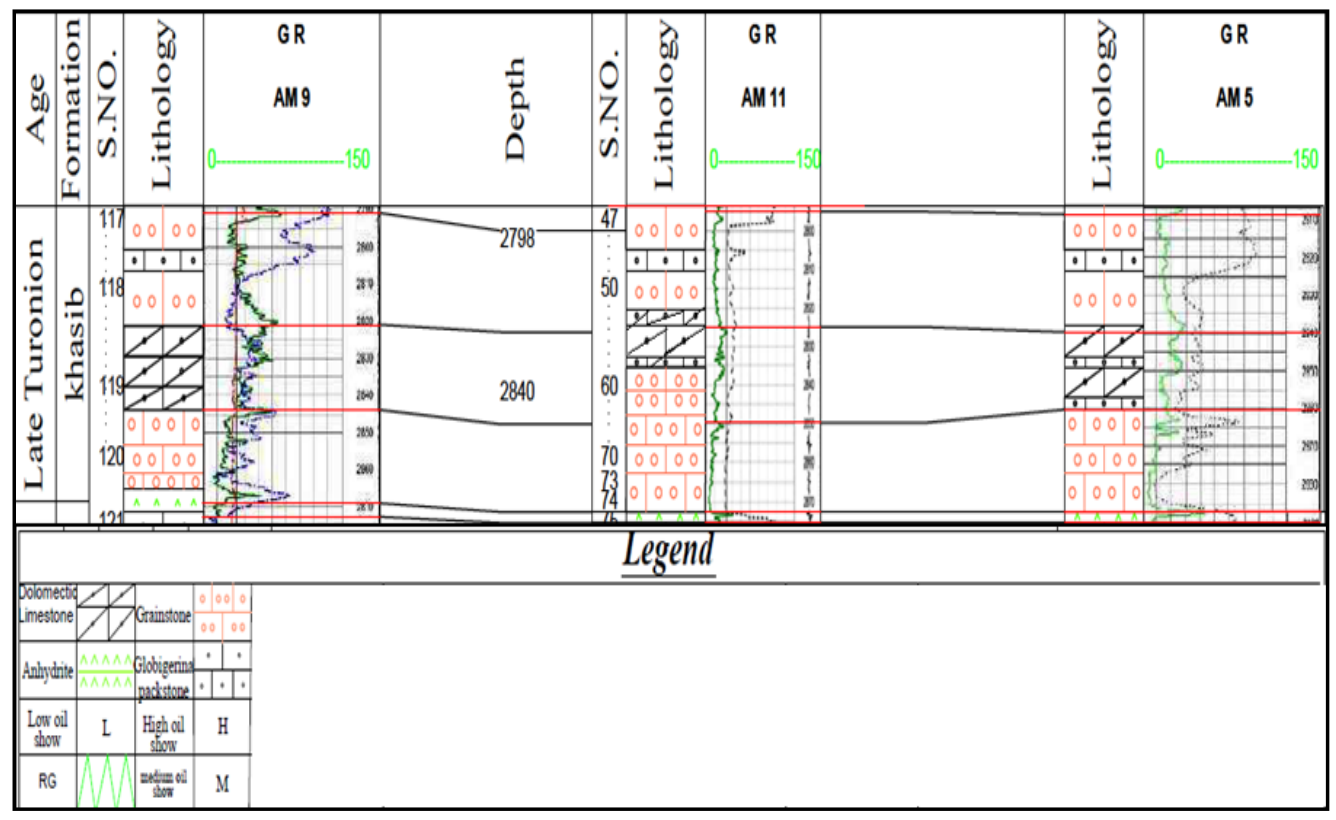

Fig. 4: Correlation section of study well in the Amara oil field of the Khasib Formation

1. The correlation section has shown the dolomitic limestone (BAR2) in Khasib Formation specified in:

\begin{tabular}{|c|c|c|c|}
\hline Well & AM 5 & AM 9 & AM11 \\
\hline Deepness & $2856-2864 \mathrm{~m}$ & $1-2837 \mathrm{~m}$ & $2840-2841 \mathrm{~m}$ \\
\hline
\end{tabular}


2. The partly dolomitize limestone is ranging between $10-35 \%$ in Khasib Formation which is determined in:

\begin{tabular}{|c|c|c|c|}
\hline Well & AM 5 & AM 9 & AM11 \\
\hline Deepness & $1 \mathrm{~m}$ & $2820-2843 \mathrm{~m}$ & $2826-2851 \mathrm{~m}$ \\
\hline Reservoir unit & KA & KA + upper KB & KA+ upper KB \\
\hline
\end{tabular}

\section{DEPOSITIONAL ENVIRONMENT OF KHASIB FORMATION}

Microfacies distribution for Khasib in Amara oil field is an indicator to one environment setting in deep water basin. The first microfacies Globigerina Grainstone indicates SMF 3-FOR pelagic foraminifera according to (Wilson, 1975) classification and featured with good diversity for Globigerina genus in microspar ground mass. Most researchers link between this genus (Globigerina) and the deep marin environment (under wave of the effect). This follows Globigerina packstone microfacies and also have the same criteria to deep water environment in (FZ 1) with a higher percentage of micrite. Another physical indication of description for deep water environment dark thin limestone beds, dark shale beds rock color dark brown, black (due to organic matter) and reddish due to slow sedimentation as notable in the core of study wells (Luterbacheret et al., 1984).

Towards the highest of the formation, Calpionellids packstone microfacies was noted. The calpionellids fauna is $75 \%$ percentage in miritic groundmass specified in SMF 3-CALP (calpionellids) according to (Wilson, 1975) classified and give another guide of (FZ1) in deep sea water. According to (Cook, 1983) he suggests a Calpionellids shield which is located quiet and warming water, lived in three environments in deep water and central environment between the deep to shallow (Rudist). The study determines the environment of Calpionellids depends on the fossils associated with it such as Globigerina in studied well. 

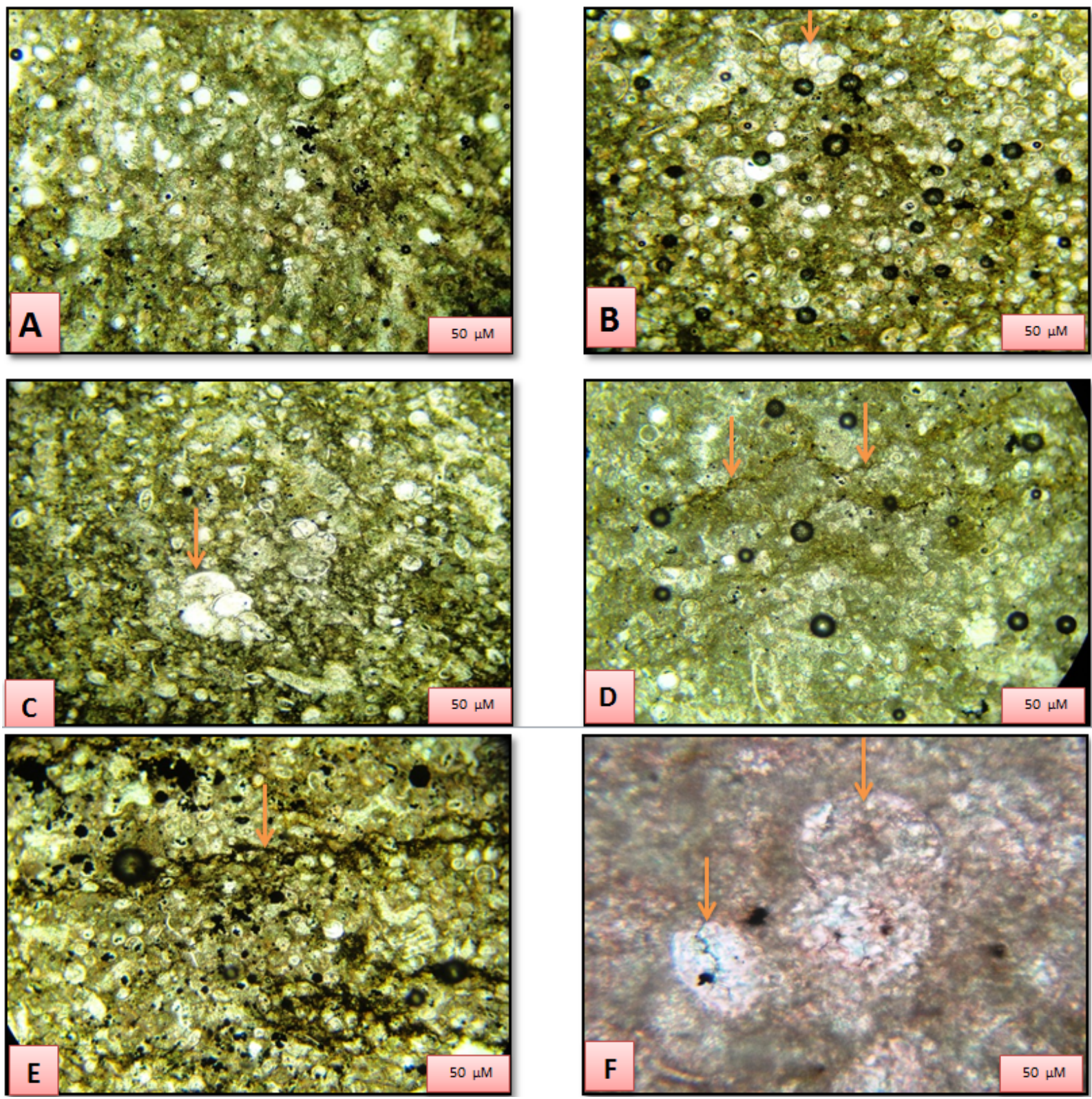

Plate 1: (A) Globigerina Spherical in Khasib Formation at depth $(2810 \mathrm{~m})$ S.NO (52) in well AM11 (B) Globigerinid Note the globular chambers in Khasib Formation at depth (2817 m) S.NO. (59) in well AM11. (C) Herohelix in Khasib Formation at depth (2805 m) S.NO. (47) in well AM11. (D) Stylolite in Khasib Formation at $(2807 \mathrm{~m})$ S.NO. (49) in well AM11 (E): Note dark insoluble residue pressure-solution (material that has at stylolite interfaces) in Khasib Formation in well AM11. (F) Microcrystalline texture in Khasib Formation at depth $(2820 \mathrm{~m})$ S.NO. (62) in well AM11 

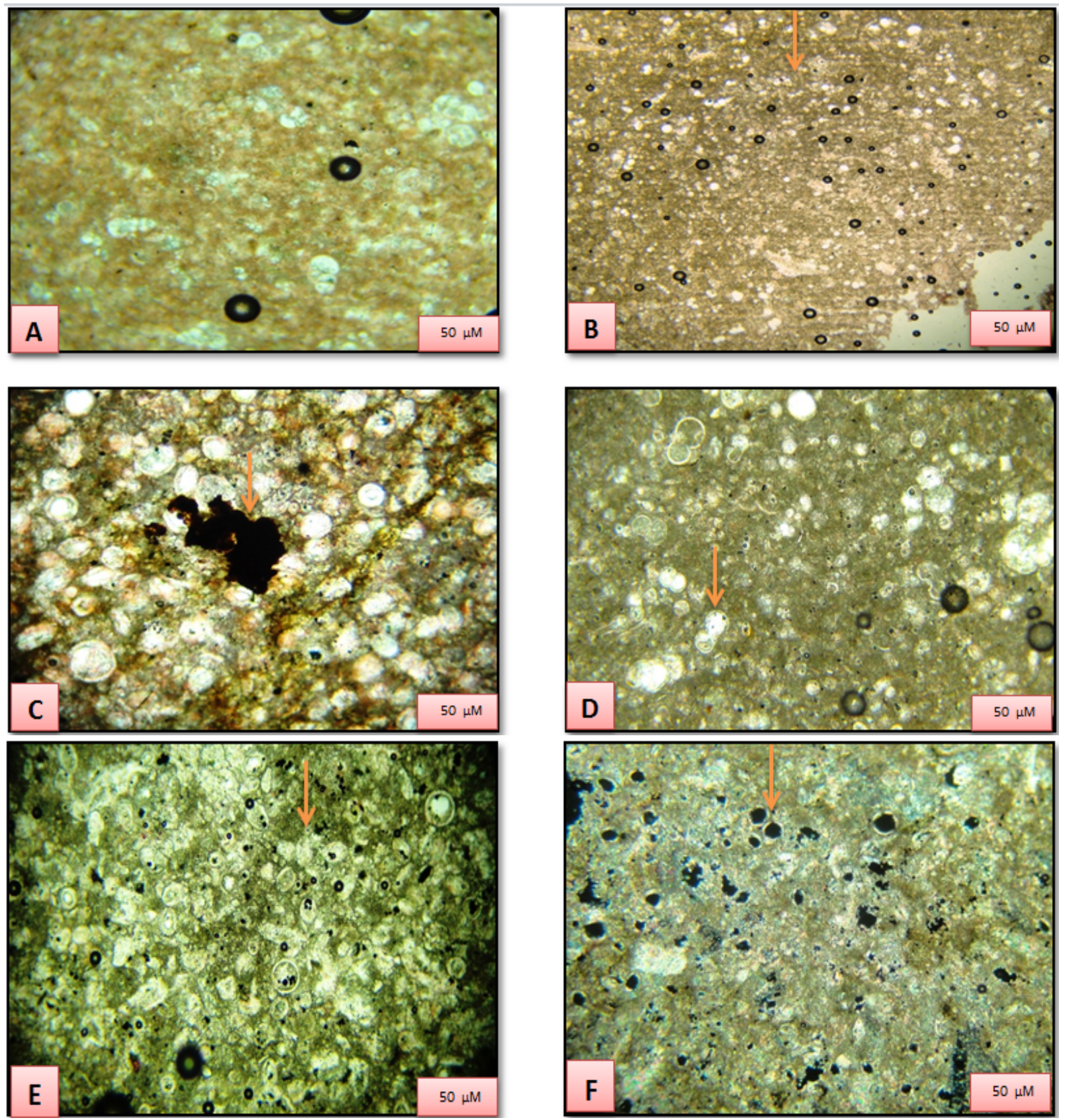

Plate 2: (A) Dolomitization distortion Facies and fossils in Khasib Formation at depth (2828 m) S.NO. (69) in well AM11. (B) Laminated micrite in Khasib Formation at depth $(2820 \mathrm{~m})$ S.NO. (62) in well AM11. (C) pyrite in Khasib Formation (2816m) and S.NO.(56) in well. (D) Praeglobotruncana in Khasib Formation at depth $(2820 \mathrm{~m})$ S.NO. (62) in well AM11. (E) Calpionellids are bell-shaped very small calcite in Khasib Formation at depth (2811 m) S.NO. (53) in well AM 11. (F) Moldic pores in Khasib Formation at (2812 m) S.NO. (54) in well AM11 

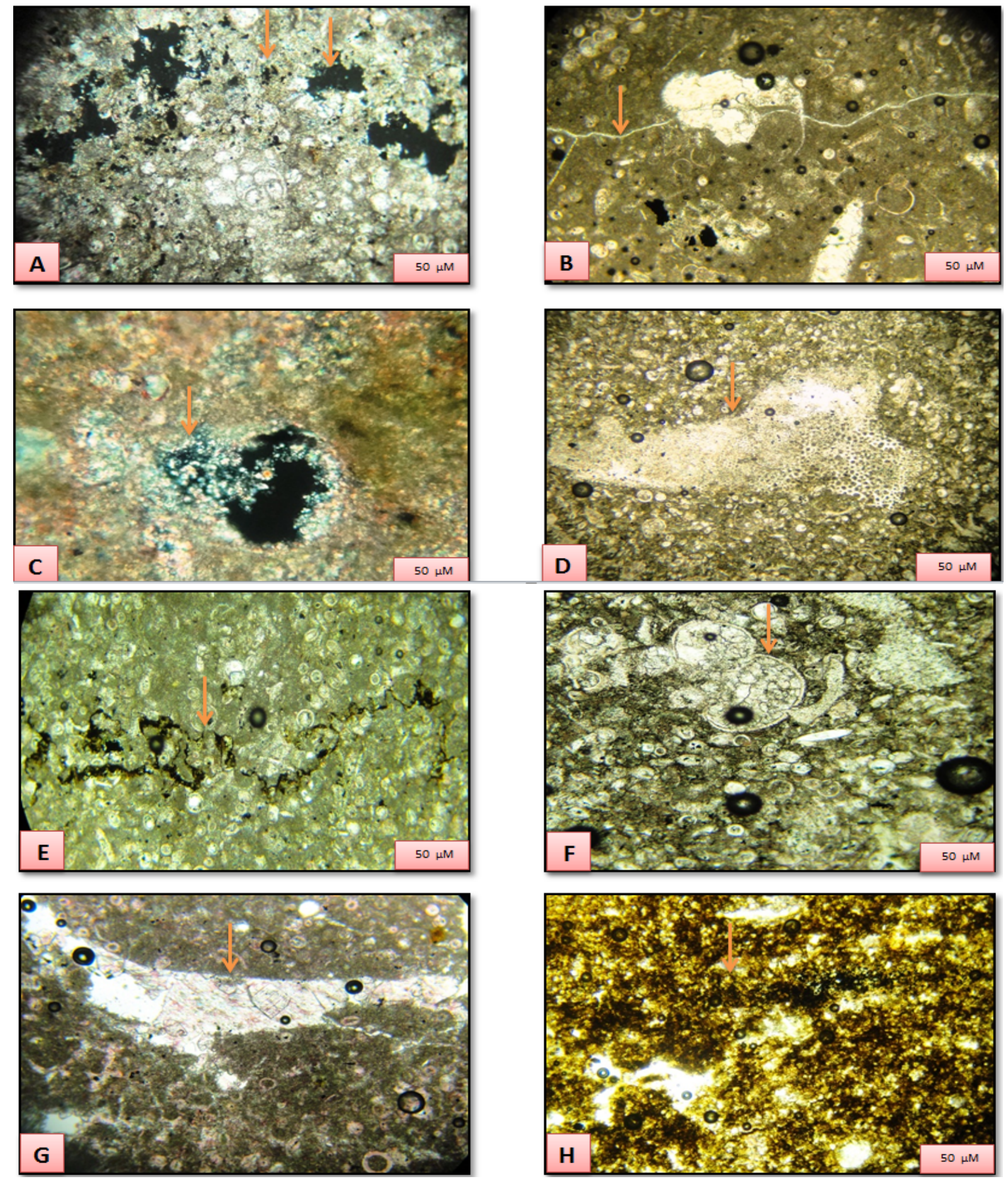

Plate 3: (A) Interparticle pores in Khasib Formation at (2805 m) S.NO. (47) in well AM11. (B) Fracture and cavern pores fill by cement in Khasib Formation at depth $(2827 \mathrm{~m})$ S.NO (68) in well AM11 . (c): Intercrystalline pores in Khasib Formation at depth (2831 m) S.NO. (81) in well AM11. (D) Rudist tabular as bioclast in Khasib Formation at depth (2812 m) S.NO. (54) in well AM11. (E) irregular Stylolitein AM11 S.NO 68 at depth 2827m (G) large calcite crystals in Khasib Formation at $(2808 \mathrm{~m})$ S.NO. (50) also have two set cleavage by effect of deformation in Burial environment in well AM11.H: high oil shows in KB unit in globigerina Grainstone microfacies (GG3) in S.NO (71) in depths 2831 m. 


\section{THE KHASIB FORMATION FACIES MODELS}

To build 3D facies model, the model requires two key steps. The first step is facies characteristics and direction trend that should be explained by sedimentological description. The second step is application for this data and correlation in the simulation model. This model can be used for quality control and development plans (Cannon, 2018).

In the current study, according to (Schlumberger, 2015) it uses algorithm truncated aussian with trends for 2D and 3D Facies model of the Khasib Formation (Figs. 5 \& 6). These were built depending on the results of the microfacies description (analyses) and interpretation of sedimentary environments from thin section and also core description and log interpretation of five wells in the Amara oil field area in the petrel software (Schlumberger, 2015).

The 2D and 3D facies models noted the distance between AM12 to AM3 reached to 10.5 $\mathrm{km}$. The dipocenter is located between AM11, AM13 wells by the deep basin facies. The facies distributions in the sedimentary basin show the Globigerina Grainstone microfacies as a main component of the Khasib Formation in the lower part. The Globigerina packstone microfacies and Calpionellids packstone microfacies are concentrated in the upper part (dipocenter) of the Khasib Formation and decreasing in facies thickness toward the east in AM3 and toward west AM12. The facies pattern in the sedimentary basin has a balance between the absorption basin and the size of the sediments and the stability of the depositional environment throughout the deposition.

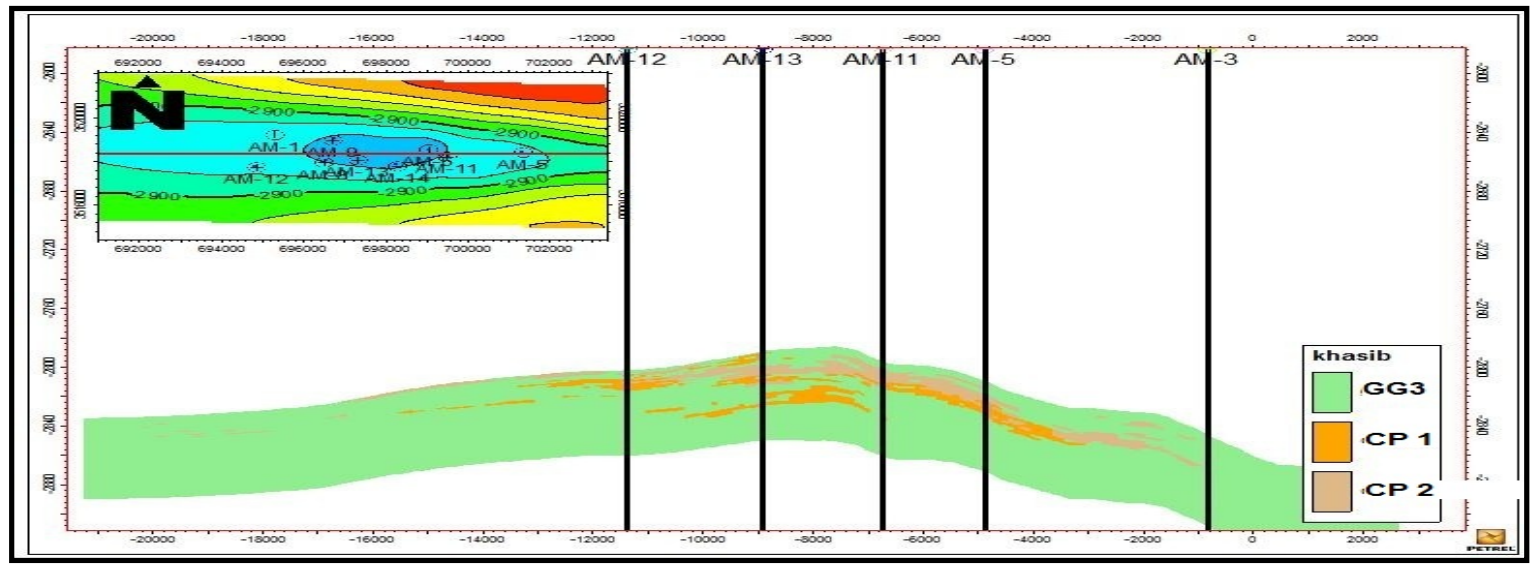

Fig.5: 2D modeling facies in Khasib Formation, GG3: Globigerina Grainstone microfacies, CP1: Globigerina packstone microfacies, CP2: Calpionellids packstone microfacies 


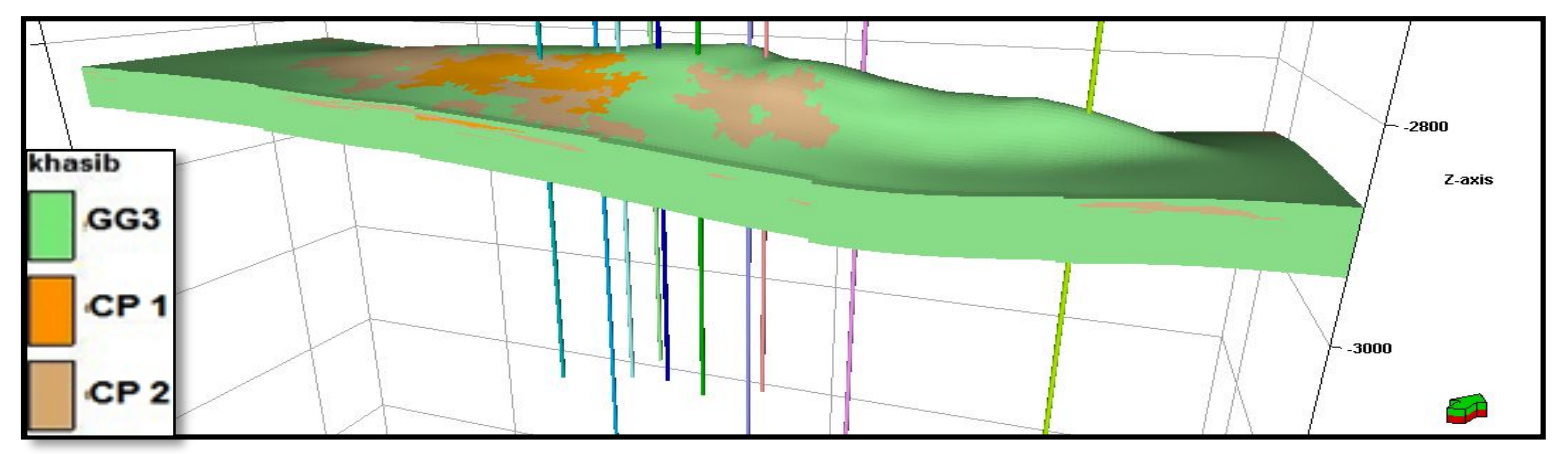

Fig.6: 3D modeling facies in Khasib Formation .GG3: Globigerina Grainstone microfacies, CP1: Globigerina packstone microfacies, CP2: Calpionellids packstone microfacies

\section{LAYERING MODEL OF KHASIB FORMATION}

It is defined as the internal layering reflecting the geological deposition of a specific zone. Layers only sub-divide the grid between the zone-related horizons (Schlumberger, 2015) For another sense of knowing stratigraphic levels represented by seismically interpretation, horizons/events and geologically significant surfaces identified in well data. The levels are identified in both data sets then the mapped seismic horizons are constrained by the well picks (Cannon, 2018).

The dipocenter is located between AM11, AM13 wells by the deep basin facies. The facies distributions in the sedimentary basin show the Globigerina Grainstone microfacies as a main component of the Khasib in the lower part. The Globigerina packstone microfacies and Calpionellids packstone microfacies are concentrated in the upper part (dipocenter) of the Khasib and decreasing in facies thickness toward the east in AM3 and toward west AM12. The facies pattern in the sedimentary basin has a balance between the absorption basin and the size of the sediments and the stability of the depositional environment throughout the deposition. Khasib reservoir has been divided into 45 layers depending on log behavior, petrophysical properties and facies to capture any change (Fig. 7) illustrate the layering of Khasib Formation. It was interpreted accordingly to Sequential number (Sec.NO) as it is shown in the (Figure 3) which represents the change in microfacies from the bottom to top. The number of layers has been distributed to each successive Microfacies as Sec.NO21=14 layers, 22=4 layers ,23 =7 layers, 24=6 layers, $25=4$ layers, 26=10 layers.

According to (Cannon, 2018) there are many applications of the layering models that might be summarized by: (1- off-lap or on-lap/down-lap sequences,2-highstand system tract tends to become eroded if it is followed by a lowstands, that is, strata are truncated by the top surface.3- used for laterally extensive sheet-like bodies or to replicate differential compaction in a shale sequence; in this case, there will be a constant number of cells in the vertical stack.) 


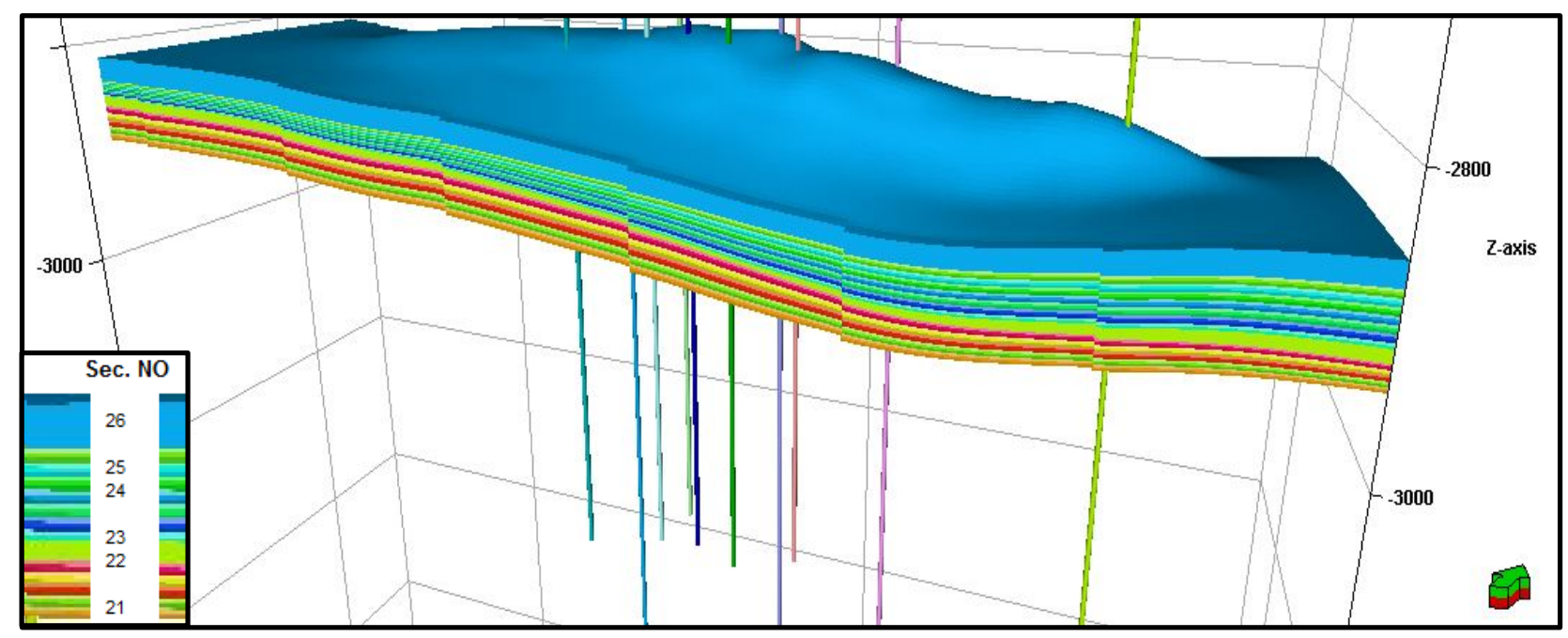

Fig.7: The Layering in the Khasib Formation in Amara Oil Field

\section{ACKNOWLEDGEMENTS}

The authors would highly thank, Missan Oil Company, Oil exploration company and Ministry of Education, Iraqi Journal staff and reviewers for publishing the research efforts. We also, would specially thank people who have supported and encouraged us during these efforts.

\section{REFERENCES}

Buday, T., 1980. The Regional Geology of Iraq. Stratigraphy and Paleogeography. Baghdad: Publication of Geosurv.Dar AL-Kutub published House Mosul.

Budd, D.A., 2002. The relative roles of compaction and early cementation in the destruction of permeability in carbonate grainstones. A case study of the Paleogene of west-central Florida, U.S.A. Journal of Sedimentary Research 72(1):116-128.

Cannon, S., 2018. Reservoir Modelling A Practical Guide, First Edition. Steve Cannon. (C) 2018 JohnWiley and Sons Ltd. Published 2018 by JohnWiley\& Sons Ltd.

Choquette, P.W., and Pray, L.C., 1970. Geologic Nomenclature and Classification of Porosity In Sedimentary Carbonates. American Association of Petroleum Geologists Bulletin, 54: 207-250.

Cook, H.E., and Enos, P., 1979. Deep-Water Carbonate Ensuing Cluster Analysis and Factor Analyses and Evhuvironments. Society of conomk Paleontologists and Mineralogists, Special Publications, 25, 336 pp.

Darmoian, S.A., 1975. Stratigraphy and micropaleontology of the Upper Cretaceous Aeuma Super Group Southeast Iraq. Jour.Geo.soc.Iraq, Sp. Issu, 89-116.

Bellen, R.C., Dunnington, H.V., Wetzel, R. and Morton, D., 1959. Lexique Stratigraphic International. Asie, Fasc. 10a, Iraq, Paris.

Dunham, R.J., 1962. Classification of Carbonate Rocks According to Depositional Texture. In Ham, W.E. (ed), Classification of Carbonate Rocks, A.A.P.G Me.-1, Tulsa, Okla., 108-12 pp.

Flugel, E., 2010. Microfacies of Carbonate Rocks: Analysis, Interpretation and Applications, 2nd. Edition: Springer-Verlag, Berlin.

Hassan, M., 1973. Radioelements and Diagenesis in Shale and Carbonate Sediments. Said 2nd Ann. Symp. Trans, $14 \mathrm{pp}$.

Jassim, S.Z. and Goff, J.C., 2006. Geology of Iraq. Czech Republic: Dolin, Prague and Moravian Museum, Brno.

Lucia, F.J., Kerans, C., and Wang, F.P., 1995. Fluid-flow characterization of dolomitized carbonate-ramp Reservoirs. SEPM, Society for Sedimentary Geology), SEPM Short Course 34:129-153.

Lucia, F.J., 2007. Carbonate Reservoir Characterization. An Integrated Approach, 2nd Edition. Springer-Verlag Berlin, Heidelberg. 
Luterbacher, H.P., Van Hinte, J.E., 1984. Deep-Water Paleobathymetry, Palaeogeography, Palaeoclimatology, and Palaeoecology, Special Issue, 48.

Tucker, M.E., 2001. Sedimentary and Petrology. An Introduction to the Origin of Sedimentary Rocks. BSc, PhD, FGS, CGeol. Department of Geological Sciences University of Durham.

Missan Oil Company M.O.C., 2011. final geological reports, proposals, charts and maps of Amara Field. Unpublished reports.

Randazzo, A.G., and Zachos, L.G., 1984. Classification and description of dolomitic fabric of rock from the Florida Aquifer. U.S.A. Jour. Sed. Geii., 37(3):151-162.

Schlumberger, 2015. Petrel property modeling course, A Schlumberger company, 544pp.

Wilson, J. L., 1975. Carbonate Facies in Geologic History. Springer Verlag, Berlin, 475 pp.

Owen, R.M.S., and Nasr, S.N., 1958. Stratigraphy of the Kuwait-Basra Area. In Weeks, L.G., Ed., Habitat of Oil, AAPG, Memoir 1, 1252-1278. 